\title{
Effect Of Exposure To Wi-Fi Router Radiation On The Lung Of Adult Male Albino Rats: Histological And Immunohistochemical Study
}

Original

Article

\author{
Randa Ahmed Ibrahim, Azza Hussein Ali, Noura Hassan Khamis, and \\ Hanaa Hassanein Mohammed
}

Department of Histology and Cell Biology, Faculty of Medicine, Minia University, Egypt

\begin{abstract}
Introduction: Recent years have witnessed a marked increase in use of Wi-Fi devices in daily life. This new technology was approved to cause many health hazards.

Aim of the Work: To investigate the histological structure changes occurred in the lung of the adult male albino rats after short and long time exposure of Wi-Fi router devices.

Materials and Method: This study was carried out on 30 adult male albino rats. They were exposed to the $2.45 \mathrm{GHz}$ radiation from Wi-Fi router device which was placed at $25 \mathrm{~cm}$ from the animals. Animals were divided into 3 groups 10 rats each: Group I (control): Rats were isolated in a room away from router device. Group II (6 hours): Rats were exposed to router device for 6 hours per day for 30 days. Group III (24 hours): Rats were exposed to router device for 24 hours per day for 30 days. Histological, immune-histochemical (Caspase 3 and iNOS antibodies), and morphometric studies were done.

Results: Both 6 hours and 24 hours groups showed marked histological and immune-histochemical changes in the lung tissues when compared with the control group, however, changes in the 24 hours group is more severe when compared with the 6 hours group.

Conclusion: Nowadays, the utilization of Wi-Fi routers devices becomes unavoidable in work and inside our homes. So, if we fail to control the radiation exposure time many people are likely to become sick. From this study, the exposure to such devices can cause bad effects on the lung tissue which increases with prolonged exposure time. So we should control the usage of these devices to save our health.
\end{abstract}

Received: 17 January 2019, Accepted: 17 February 2019

Key Words: Electromagnetic field (EMF), electromagnetic radiation (EMR), lung, router device, wireless fidelity (Wi-Fi).

Corresponding Author: Randa Ahmed Ibrahim, MD, Department of Histology and Cell Biology, Faculty of Medicine, Minia University, Minia, Egypt, Tel.: +20 1002930491, E-mail: randaahmed11@yahoo.com

ISSN: 1110-0559, Vol. 42, No. 4

\section{INTRODUCTION}

In recent years, both at work and at home everyone is exposed to electromagnetic field (EMF) arising from telecommunications and broadcasting apparatus ${ }^{[1]}$. Mobile phones and Wireless Fidelity (Wi-Fi) are among the main sources of the exposure the population to radiofrequency electromagnetic fields (REF) ${ }^{[2]}$. The Wi-Fi devices allow the exchange of data through their waves. The devices that use Wi-Fi are such as wireless routers, tablet, personal computers, audio player, and cell phone ${ }^{[3]}$. Emerging technology such as router devices operating at $2.45 \mathrm{GHz}$ has recently seen broadly and become more needed in daily life ${ }^{[4]}$.

The level of radiofrequency electromagnetic radiation in the world will rise quickly. So, attention should paied about this electromagnetic pollution. Some hazards effects of EMF exposure have been reported such as triggering oxidative stress in various tissues, and changing in levels of blood antioxidant markers significantly ${ }^{[5]}$. Recent studies revealed that exposure to radiation emitted from Wi-Fi technology has many health hazards on different body organs such as; $\operatorname{Brain}^{[6]}$, liver ${ }^{[7]}$, kidney ${ }^{[8]}$, heart ${ }^{[9]}$, pancreas $^{[10]}$, reproductive system ${ }^{[11]}$, blood ${ }^{[12]}$. This radiation carries also risk of cancer ${ }^{[13]}$.

\section{MATERIALS AND METHODS}

\section{Experimental animals}

Thirty healthy adult male albino rats 6-8 weeks age weighting approximately 150-250 grams were obtained from laboratory animals growing center of faculty of agriculture, Minia University. Rats were housed in clean plastic cages and fed a standard laboratory diet with free access to water and diet. Rats were maintained at a room temperature ranged from $24-30^{\circ} \mathrm{C}$ and exposed to 12 hours light and 12 hours dark cycle. All aspects of animal care and treatment were carried out according to the local guidelines of the ethical committee of faculty of medicine of Minia University.

\section{Experimental design}

The Wi-Fi signal was picked up directly by a commercial access point for use indoors (ZTE -ZXHN 
H108N Router with $802.11 \mathrm{~g}$ mode and WPA2 net-work protection $)^{[14]}$. The device supports wireless networking speeds of up to $150 \mathrm{Mbps}$ (Turbo mode) on the popular $2.4 \mathrm{GHz}$ public frequency. Exposed groups were placed in cages which were placed at a distance of $25 \mathrm{~cm}$ from the router device ${ }^{[9]}$. The cages of exposed group were surrounded with electromagnetic absorber material backed by metal to isolate outdoor electromagnetic fields from the test setup during the study duration of 30 days.

The 30 adult male albino rats were randomly divided into 3 groups ( $\mathrm{n}=10$ per group). The group I (control group) was isolated in a separate room isolated from radiation source and the router switch off $(0 \mathrm{~Hz})$. The group II (6 hours group) was exposed to radiations emitted from the Wi -Fi router device for 6 hours per day from 9 am to $3 \mathrm{pm}$ and the group III (24 hours group) was exposed for 24 hours per day.

For light microscope examination: At the end of the experiment (30 days), rats were sacrificed by decapitation under light halothane anesthesia, the lung specimens were taken then dissected and rapidly fixed in 10\% formal saline for 48 hours, then they were washed by tap water and processed for paraffin embedding. Sections of 5 microns were cut and stained with Hematoxylin and Eosin (HandE) and Masson's trichrome for their histological examination $^{[15]}$.

Four rats from the different groups were slowly intravenously injected with $0.3 \mathrm{ml}$ aqueous buffered solution formed of suspension of carbon particles $(0.5 \mathrm{ml})$ in normal saline $(100 \mathrm{ml})$, five hours before the sacrifice. This was to determine the phagocytic uptake of the carbon particles by the macrophages ${ }^{[16]}$.

Staining technique for Immunohistochemical studies: Immunocytochemical staining was performed according the manufacture instructions using polyclonal rabbit antibodies for anti-cleaved caspase 3 (PA1-26426) and anti inducible nitric oxide synthase (PA1-036) (iNOS) antibodies which were obtained from sigma aldrich. Sections were deparaffinised, hydrated then washed in $0.1 \mathrm{M}$ phosphate buffer saline (PBS). Endogenous peroxidases were quenched by treatment with $\mathrm{H}_{2} \mathrm{O}_{2}$ in methanol (Peroxidase blocking solution) followed by washing in tris buffer saline (TBS). Non-specific binding of IgG was blocked using normal goat serum, diluted 1:50 in $0.1 \%$ bovine serum albumin with TBS for 30 minutes. The sections were incubated with the diluted primary antibodies for cleaved caspase 3 (1:200) and anti-iNOS antibody (1:100). Sections then washed 3 times each for 5 minutes in buffer and incubated for further 30 minutes with biotinylated goat anti-rabbit secondary antibodies diluted 1:1000, followed by washing. Following further 30 minutes incubation with Vectastain ABC kits (Avidin, Biotinylated horse radish peroxidase Complex) and washing for 10 minutes, the substrate, diaminobenzidine tetra hydrochloride (DAB) in distilled water was added for $5-10 \mathrm{~min}$. The slides were lightly counterstained by hematoxylin and dehydrated by passing through ascending concentrations of alcohol then cleared by xylene. Negative control for activated caspase- 3 and iNOS were performed by the same steps of immunostaining but the primary antibodies were removed. The same technique was applied to prepare negative control sections but without the primary ab. Tonsils were used as a positive control for activated caspase. Lung tissue is considered positive control for iNOS according to the company instructions.

\section{Photography}

Olympus light microscopy (Olympus, Japan) was used for examining and capturing images for the histological and immunohistochemical sections. At light microscopic unit of histology and cell biology department, faculty of medicine, Minia University.

\section{Morphometric study}

Morphometric analysis of mean number of macrophages in three groups was done at $\times 400$ magnification. The macrophages (marked by the yellowish brown color of the engulfed charcoal) were counted at $\times 400$ magnification in 10 non overlapping fields for each HandE stained slides of all groups ${ }^{[17]}$. Image $\mathrm{J} 22$ software in the faculty of Dentistry, Minia University was used for area fraction measurement of the activated caspase $3^{[17]}$ and $\operatorname{iNOS}^{[18]}$ immunopositivity. Area fraction was measured in a standard measuring frame per 10 photomicrographs in each group using a magnification $\times 400$ by light microscopy transferred to the monitored screen.

\section{Statistics}

Statistical analysis for numerical data was done by SPSS (version 20, Windows 7, Office 2010). The mean number (MN) and standard deviation (SD) were determined for parameter in each group. The significance of differences observed in these groups was pooled and assessed by ANOVA test. Significance was determined as probability factor $(P$ value $) P<0.05$.

\section{RESULTS}

\section{Histological results}

The lung of the control group stained with HandE showed normal histological structure which consists of alveoli, alveolar sacs, terminal bronchiole, blood vessels and thin interalveolar septa (Figures 1A and 2A). The 6 hours group showed marked histological changes in the form of marked inflammatory reactions with dilatation and congestion of blood vessels. There was thickening of the inter-alveolar septa compared to control group that were studded with marked extravasated RBCs and inflammatory cells (Figures 1B and b). Some bronchioles were seen with congested blood together with exfoliated epithelium (Figure 1b). Brown hemosiderin particles were detected within the inter-alveolar septa. Some alveoli contained homogenous acidophilic material. Some alveoli were collapsed while other was compensatory 
dilated (Figure 2 B). In the 6 hours group there was nearly the similar affection as the 24 hours group but more marked destructive changes in 24 hours group (Figures 1C and c). Cellular infiltrating marked increase but cells mainly neutrophils in 6 hours group (Figures 2B and b) and lymphocyte cells in 24 hours group (Figures $2 \mathrm{C}$ and $\mathrm{c}$ ). The use of charcoal injection for detection macrophage showed a few number of macrophage with brown particles in the control group which may be either alveolar or interstitial (Figure 3A). While in 6 hours group (Figure 3B) and 24 hours group (Figure 3C) showed marked increase in the number of alveolar macrophage cells compare to the control group. Sections stained with Masson's trichrome in the control group revealed traces amount of collagen fibers perivascular, around the bronchioles and in the thin interalveolar septa (Figures 4A and a). While 6 hours group (Figures 4B and b) and 24 hours group (Figures $4 \mathrm{C}$ and c) were appeared with a relative increase in the amount of collagen around the bronchiole, the alveolar interstitium, and blood vessels. Fibroblasts like cells also were observed.

\section{Immunohistochemical results}

Anti caspase 3 expression of the control group showed negative immune expression (Figures 5A and a). The 6 hours group showed positive immune expression in the cells lining the alveoli, the bronchioles and the cells present in the inter-alveolar septa (Figures. 5B and b). While in the 24 hours group, strong positive immune expression was detected in the cells lining the alveoli, the inter-alveolar septa and in the cells lining the bronchioles (Figures 5C and c). Tonsils tissue used as a positive control for caspas 3 and showed positive expression in the form of fine brown granules (Figure I). The lung tissue used as a negative control (Figure II). The iNOS expression of the control group showed faint immune expression in some cells in the inter-alveolar septa (Figure 6A). Both the 6 hours group (Figure 6B) and the 24 hours group (Figure 6C) showed a positive immune expression in the cells lining the bronchioles and the cells scattered in the interalveolar septa. The lung tissue used as a negative control (Figure III), also lung tissue is considered as a positive control for iNOS.

\section{III-Statistical results}

A significant increase in the mean number of macrophages in the 6 hours group if compared with the control group and significant increase in the 24 hours group if compared with the 6 hours group and a highly significant increase in 24 hours group if compared with the control group (Table 1+ Histogram 1). A significant increase in the area fraction of activated caspase-3 antibody expression in the 6 hours group if compared with control group, and significant increase in the 24 hours group if compared with the 6 group and a highly significant increase in the 24 hours group if compared with the control group (Table 2 + Histogram 2). A significant increase in the area fraction of iNOS antibody expression in 6 hours group if compared with the control group and significant increase in the 24 hours if compared with the 6 hours group and a highly significant increase in the 24 hours group if compared with the 6 hours group (Table 3+ Histogram 3 ).

1. Morphometric analysis of mean number of macrophages in three groups

2. Morphometric analysis of area fraction of activated caspase 3 immuno positive cells

3. Morphometric analysis of area fraction of iNOS immuno positive cells

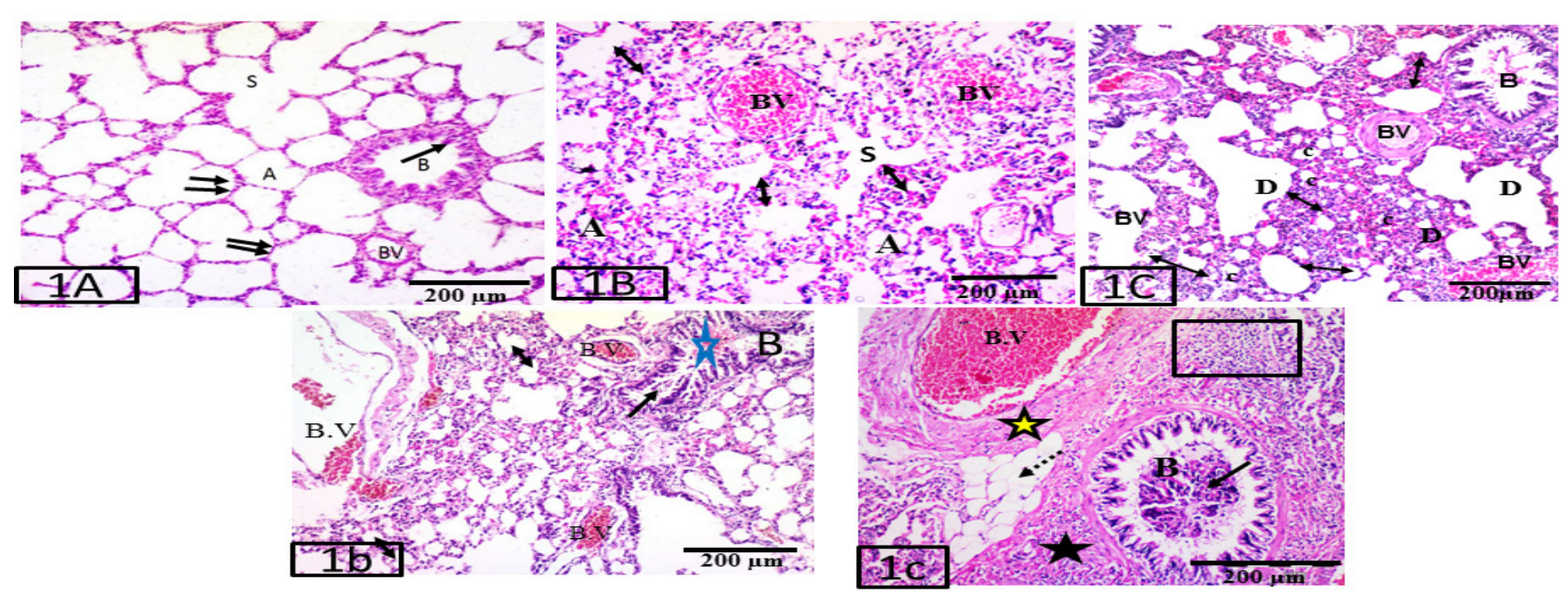

Fig. 1: Photomicrographs of adult male albino rats lung of different groups showing A: The control group showing alveoli (A), alveolar sacs (S), termina bronchiole (B) lined with simple columnar epithelium (arrow) and blood vessels(B.V). Notice thin inter-alveolar septa (double arrow). B+b: The $6 \mathrm{~h}$ group showing congested dilated blood vessels(B.V) with thick inter-alveolar septa which studded with extravasated RBCs and mononuclear inflammatory cells (double head arrows). Notice the presence of congested blood (blue star) inside bronchiole(B) which is dilated with detachment of its epithelial lining (arrow). $\mathrm{C}+\mathrm{c}$ : The $24 \mathrm{~h}$ group showing marked thickening of the inter-alveolar septa, with marked inflammatory cells infiltration and extravasated RBCs (double head arrows). Some alveoli are collapsed (c) and other are dilated (D). The congestion of the blood vessels(B.V) is obvious with peri-vascular fibrosis (yellow star). Notice the lumen of the bronchiole(B) containing exfoliated epithelial cells (arrow) with peri-bronchiolar fibrosis (black star) and mononuclear inflammatory cells infiltration is obvious (rectangle). Fat cells can be observed (dotted arrow) 

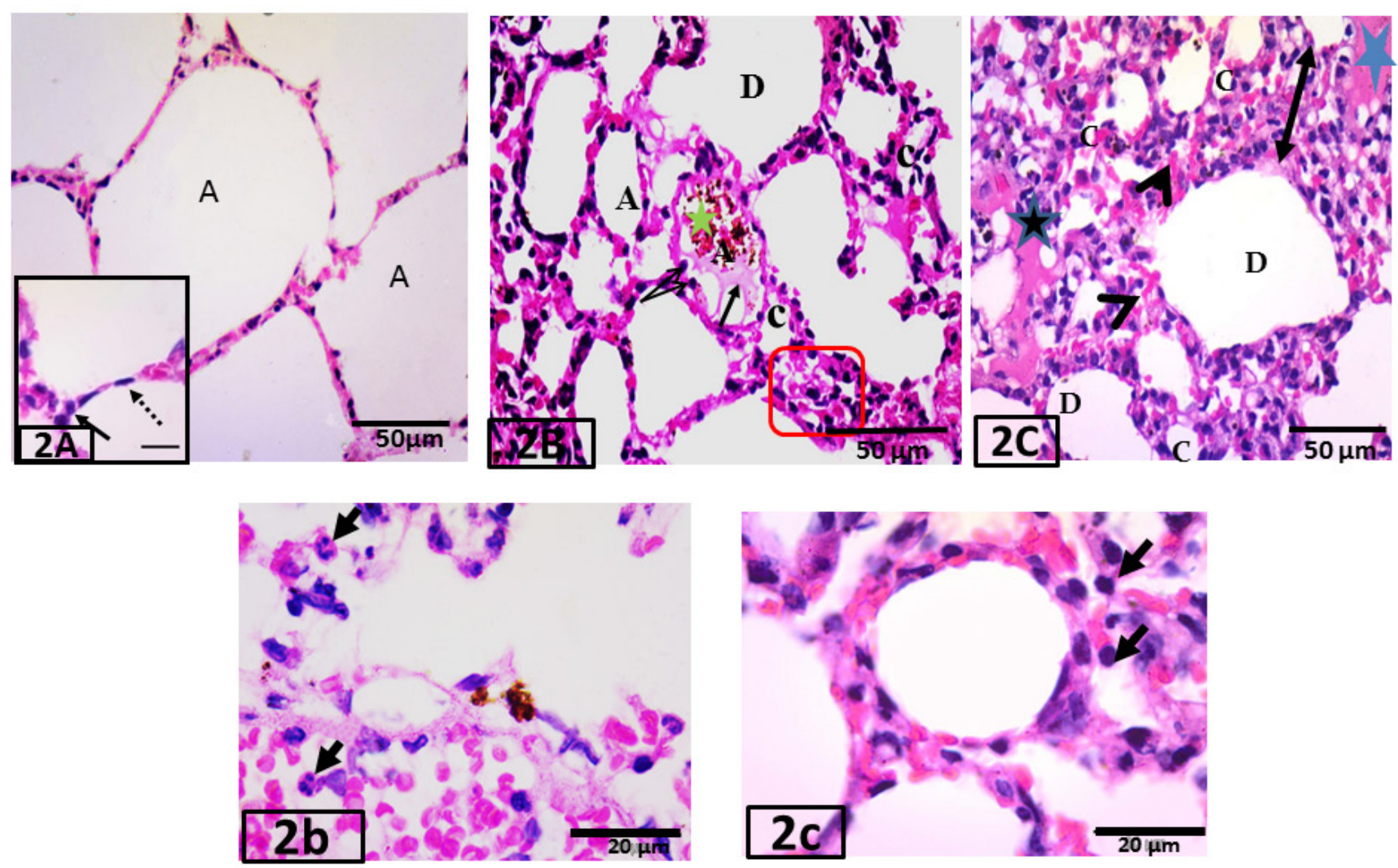

Fig. 2: Photomicrographs of adult male albino rats lung of different groups at higher magnification showing A :The control group showing alveoli (A) lined with pneumocyte type I (dotted arrow), and pneumocyte type II (arrow)(inset ). B $+\mathrm{b}$ : The $6 \mathrm{~h}$ group showing some alveoli are collapsed (C) and other are dilated (D)with many inflammatory cells mainly neutrophil (thick arrow) infiltration in the thickened inter-alveolar septum with extra vasted RBCs (red rectangle). Notice the presence of alveoli containing acidophilic homogenous material (arrow) and congested blood with hemosiderin granules (green star) - Some alveoli appear with more prominent pneumocyte type II (double arrows). C+c: The $24 \mathrm{~h}$ group showing some alveoli are collapsed (C) and other are dilated (D) and marked thickening of the inter-alveolar septa (double head arrow) which is studded with inflammatory cells mostly lymphocytes (thick arrow) and RBCs (arrow head). Notice more homogenous eosinophilic material is present within the septum (black star) and inside the alveoli (blue star). (HandE $\mathrm{x}$ 400 , scale bar $=50 \mu \mathrm{m}), \mathrm{x} 1000$, scale bar $=20 \mu \mathrm{m}$, inset scale bar $=20 \mu \mathrm{m}$ )

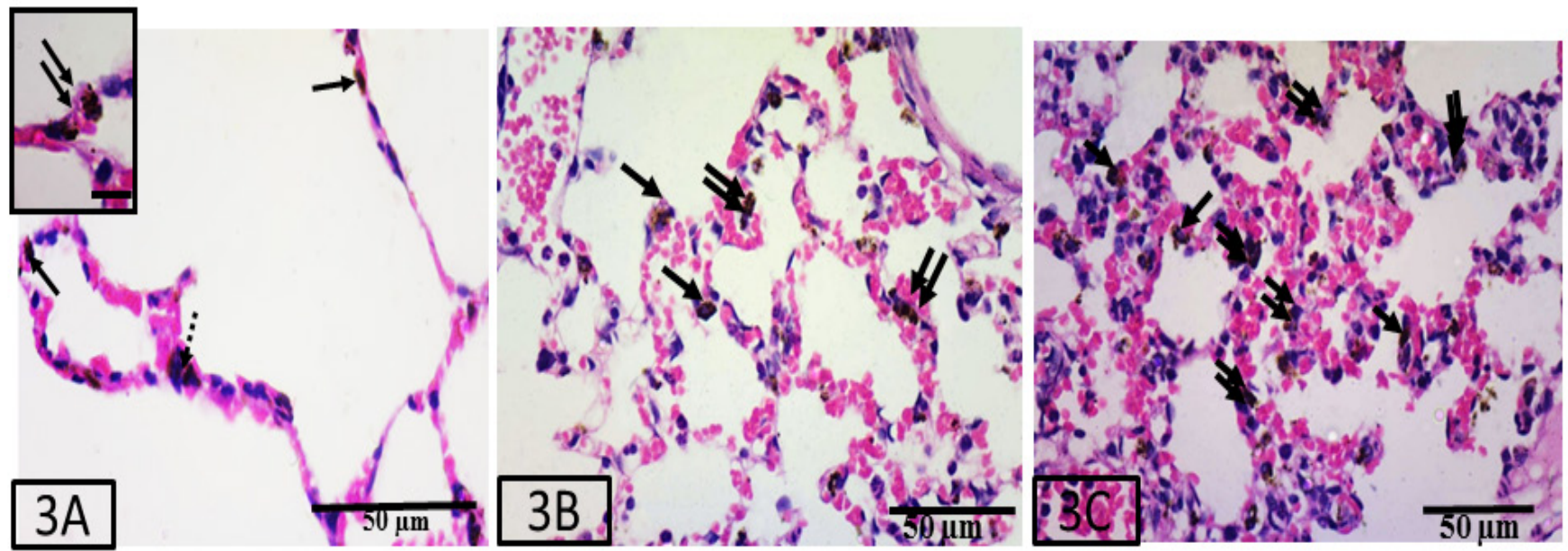

Fig. 3: Photomicrographs of adult male albino rats lung labelled with charcoal showing A: The control group showing alveolar macrophage (arrows) and interstitial macrophage (dotted arrow).The inset showing alveolar macrophage at higher magnification (double arrows). The $6 \mathrm{~h}$ group (B) and The $24 \mathrm{~h}$ group ( C ) showing more increase in number of alveolar macrophage (arrows) and interstitial macrophage (double arrows). (HandE charcoal labeled x400, scale bar $=50 \mu \mathrm{m})$. inset $\times 1000$, scale bar $=20 \mu \mathrm{m})$ 


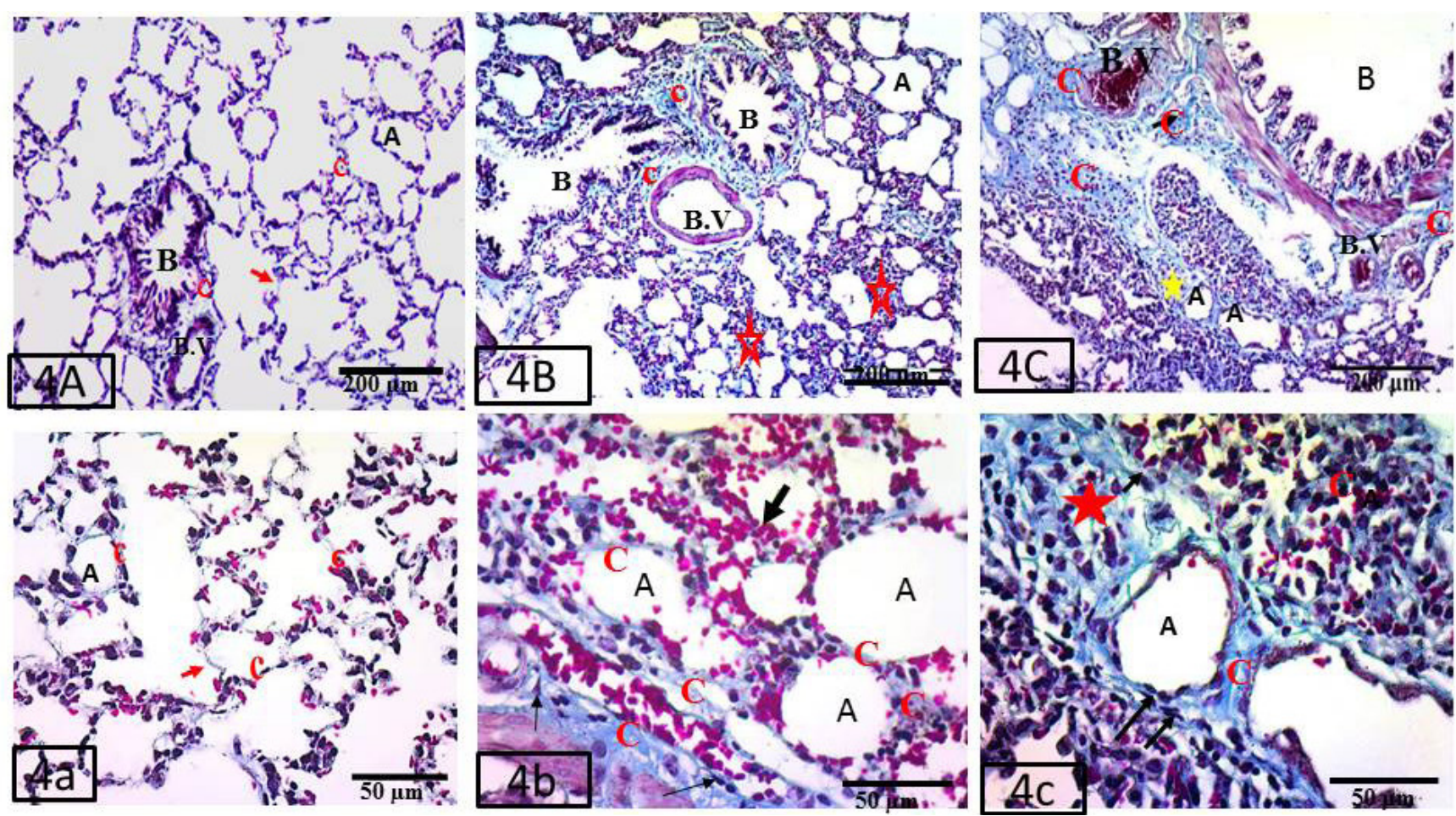

Fig. 4: Photomicrographs of adult male albino rats lung stained by Masson's trichrome showing alveoli (A), terminal bronchiole (B) ,blood vessel (B.V) and collagen fibers (c ) . A +a: The control group showing few of collagen fibers around blood vessel, bronchiole, and in the inter-alveolar septa (red arrow). $\mathrm{B}+\mathrm{b}$ : The $6 \mathrm{~h}$ group showing moderate amount of collagen fibers around the wall of the bronchiole and surrounding the wall of blood vessel. Notice collagen fibers can be also detected around alveoli and in the inter-alveolar septa (red star). Notice marked extravasated RBCs (thick arrow) around alveoli and in the interalvealar septum. Fibroblast like cells can be observed (thin arrow). C+c: The $24 \mathrm{~h}$ group showing increased amount of collagen fibers in the wall of the bronchiole, surrounding the wall of blood vessel, around alveoli (yellow star) and in the inter-alveolar septum (red star). Notice inset showing higher magnification of fibroblast like cell (arrow) (Masson's trichrome $\mathrm{x} 100$, scale bar $=200 \mu \mathrm{m}$ andx 400 , scale bar $=50 \mu \mathrm{m}$, inset $\mathrm{x} 1000$, scale bar $=20 \mu \mathrm{m}$ ).
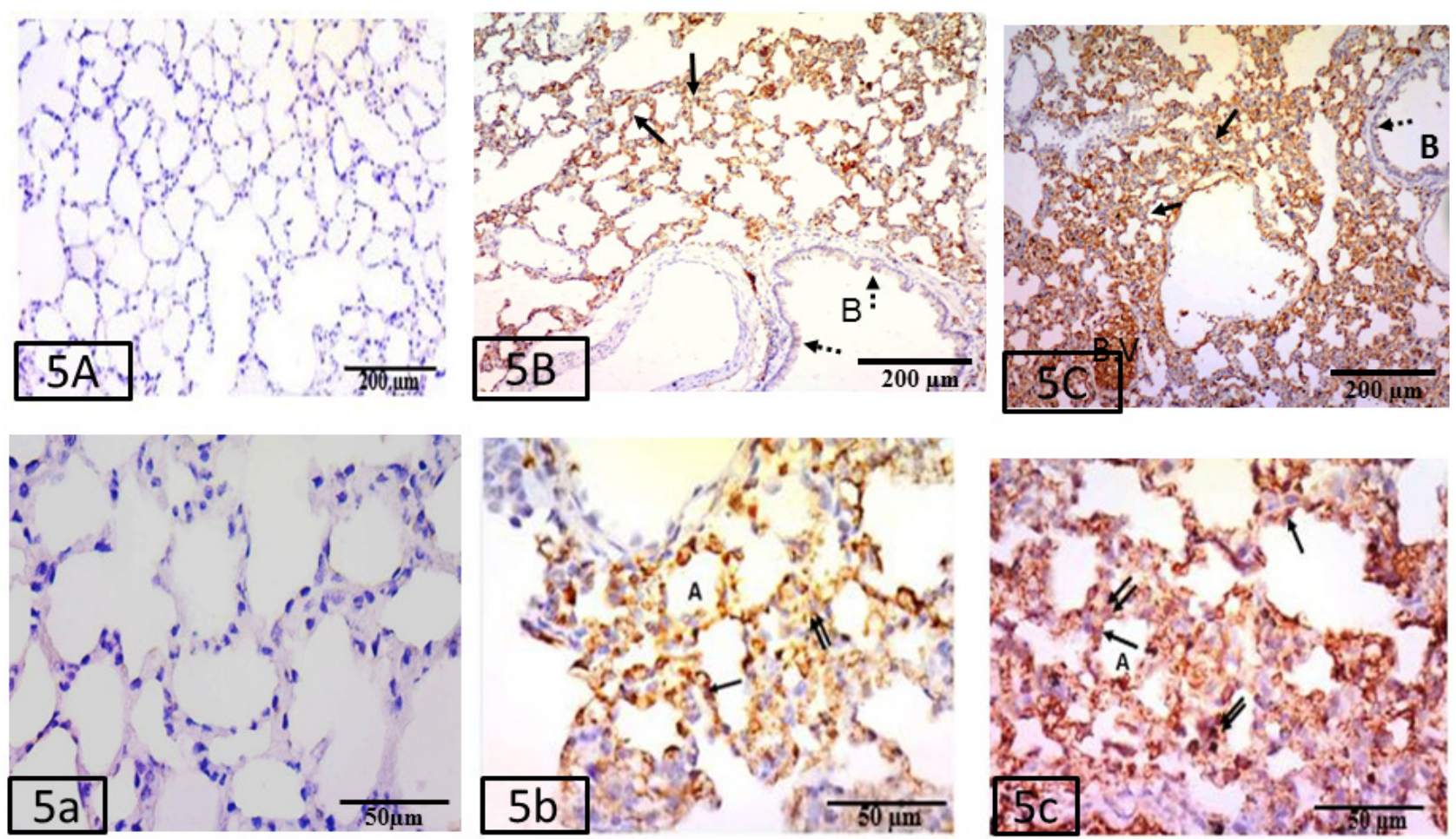

Fig. 5: Photomicrographs of adult male albino rats lung immunohistochemically stained for caspase 3 showing A+a :The control group showing negative immune expression in the cells lining alveoli. B+b : The $6 \mathrm{~h}$ group showing positive immune expression in the cells lining the alveoli (arrow), the cells lining the bronchioles (B) (dotted arrow) and the cells present in the inter-alveolar septa ( double arrows). C+c :The $24 \mathrm{~h}$ group showing strong positive immune expression in in the cells lining the alveoli (arrow), the cells present in the inter-alveolar septa (double arrows ) and in the cells lining the bronchioles (B) (dotted arrow). (IHC by caspase 3 antibodyx 100 , (scale bar $=200 \mu \mathrm{m}$ ) and $\mathrm{x} 400$, scale bar $=50 \mu \mathrm{m}$ ). 

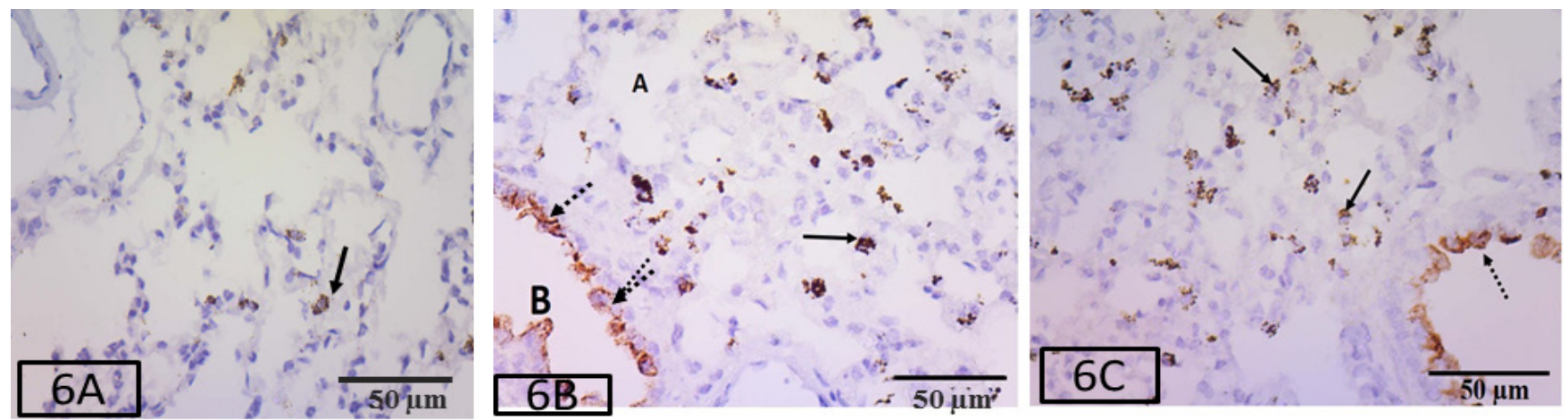

Fig. 6: Photomicrographs of adult male albino rats lung immunohistochemically stained for iNOS showing A: The control group showing faint immune expression in some cells in the inter-alveolar septa (arrow). Both the $6 \mathrm{~h}$ group (B) and The $24 \mathrm{~h}$ group $(\mathrm{C})$ showing positive immune expression in the cells lining the bronchioles (dotted arrow) and the cells scattered in the interalveolar septa (arrow). Fig III: A photomicrographe of the lung tissue used as a negative control for INOS expression (IHC by iNOS antibody $\mathrm{x} 400$, scale bar $=50 \mu \mathrm{m}$ ).

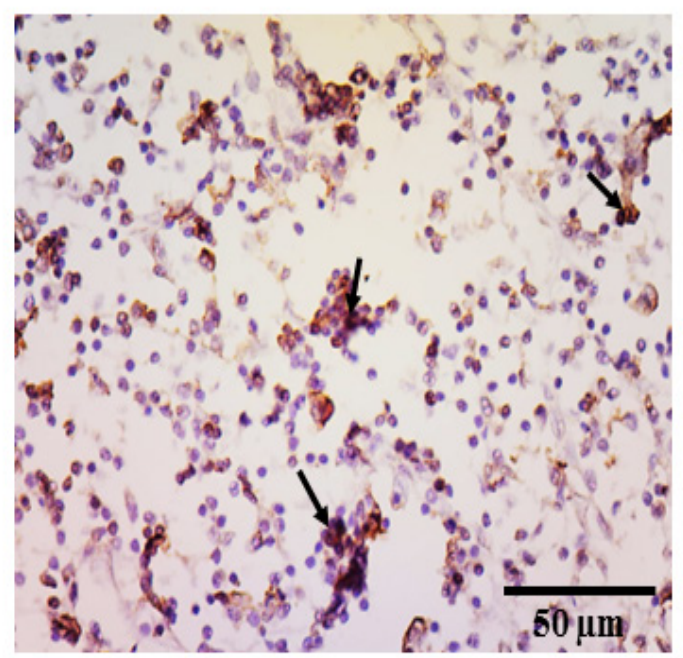

Fig. I: A photomicrograph of a section of tonsil tissue showing positive immune reaction of caspase 3 in the form of fine brown granules (arrows) in a positive control slide. (IHC by caspase 3 antibody $\mathrm{x} 400$, scale bar $=50$ Um).

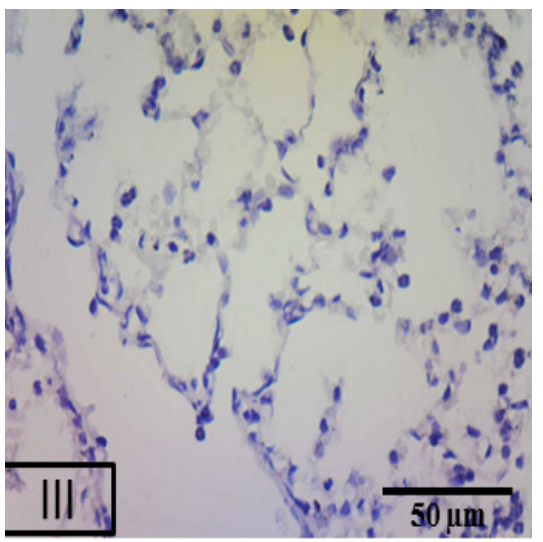

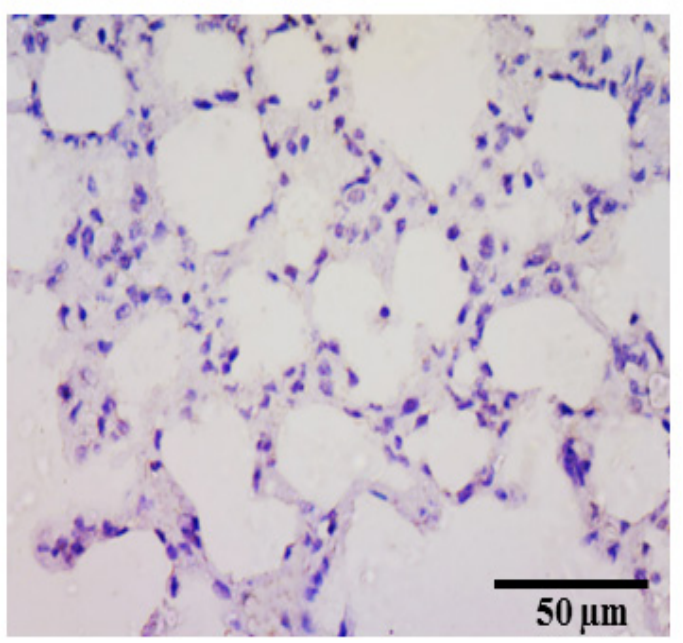

Fig. II: A photomicrograph of a negative control of caspase 3 antibody in a section of rat hung tissue at the level of alveoli. (IHC by caspase 3 antibody $\mathrm{x} 400$, scale bar $=50 \mu \mathrm{m})$.

Fig. III: A photomicrograph of the lung tissue used as a negative control for INOS expression. (IHC by INOS, scale bar $=50 \mu \mathrm{m}$ ).

Table 1: Comparison of mean number of macrophages among the three groups

\begin{tabular}{|c|c|c|c|c|c|c|}
\hline \multirow{2}{*}{ The no. of macrophage } & Control (I) & $6 \mathrm{~h}$ group (II) & $24 \mathrm{~h}$ group (III) & & \multirow{2}{*}{$P$ value } & \\
\hline & $\mathrm{N}=10$ & $\mathrm{~N}=10$ & $\mathrm{~N}=10$ & & & \\
\hline \multirow{3}{*}{$\begin{array}{l}\text { Range } \\
\text { Mean } \pm \text { SD }\end{array}$} & & & & \multirow{3}{*}{$\begin{array}{c}\text { I vs II } \\
<0.001^{*}\end{array}$} & \multicolumn{2}{|l|}{$<0.001^{*}$} \\
\hline & $(2-7)$ & $(20-29)$ & $(32-44)$ & & I vs III & II vs III \\
\hline & & & & & $<0.001^{*}$ & $<0.001^{*}$ \\
\hline
\end{tabular}

- Data are expressed as mean \pm standard deviation $*$ : Significant difference at $p$ value $<0.05$. 
Table 2: Comparison of surface area fraction for Caspase 3 antibody among the three groups

\begin{tabular}{lccccc}
\hline $\begin{array}{l}\text { Area fracture for } \\
\text { Caspase antibody }\end{array}$ & Control (I) & 6 h group (II) & 24 h group (III) & & P value \\
\cline { 2 - 4 } & $\mathrm{N}=10$ & $\mathrm{~N}=10$ & $\mathrm{~N}=10$ & $<0.001^{*}$ \\
Range & $(0.2-2.1)$ & $(21.9-28.8)$ & $(35.9-43.5)$ & I vs II & I vs III \\
Mean \pm SD & $1.3 \pm 0.6$ & $24.7 \pm 2.2$ & $39.7 \pm 2.6$ & $<0.001^{*}$ & $<0.001^{*}$ \\
& & & & $<0.001^{*}$ \\
\hline
\end{tabular}

- Data are expressed as mean \pm standard deviation *: Significant difference at $p$ value $<0.05$.

Table 3: Comparison of surface area fraction for INOS antibody among the three groups

\begin{tabular}{|c|c|c|c|c|c|c|}
\hline \multirow{2}{*}{ Area fracture for INOS antibody } & Control (I) & $6 \mathrm{~h}$ group (II) & $24 \mathrm{~h}$ group (III) & & \multirow{2}{*}{$P$ value } & \\
\hline & $\mathrm{N}=10$ & $\mathrm{~N}=10$ & $\mathrm{~N}=10$ & & & \\
\hline \multirow{3}{*}{$\begin{array}{l}\text { Range } \\
\text { Mean } \pm \text { SD }\end{array}$} & \multirow{3}{*}{$\begin{array}{c}(4.6-7.6) \\
6.1 \pm 1\end{array}$} & \multirow{3}{*}{$\begin{array}{r}(10-14.7) \\
12.7 \pm 1.4\end{array}$} & \multirow{3}{*}{$\begin{array}{c}(20.2-26.8) \\
23.9 \pm 2\end{array}$} & & $<0.001^{*}$ & \\
\hline & & & & I vs II & I vs III & II vs III \\
\hline & & & & $\leq 0001^{*}$ & & $<0001^{*}$ \\
\hline
\end{tabular}

- Data are expressed as mean \pm standard deviation $*$ : Significant difference at $p$ value $<0.05$

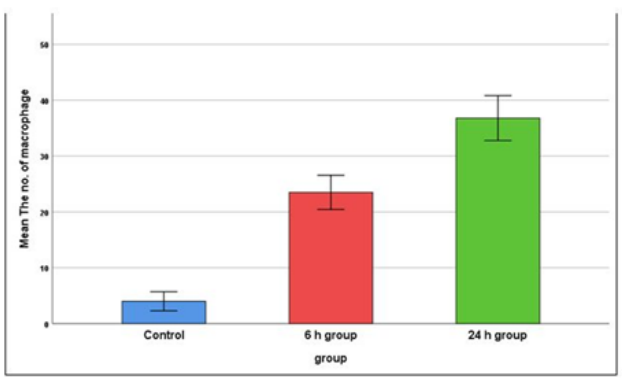

Histogram I: Comparison of mean number of macrophages among the three groups

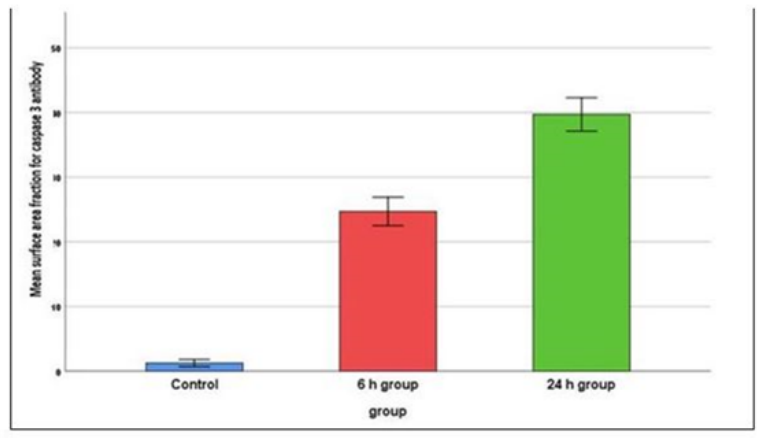

Histogram II: Comparison of mean surface area fraction of caspase 3 among the three groups

\section{DISCUSSION}

Nowadays we live in a world that becomes trapped in an electromagnetic radiation (EMR) resulted from marked increase in usage of wireless devices. These devices have become an important thing in every home, schools, universities, coffee shops, and all governmental institutions ${ }^{[19]}$. Many researches on the effect of exposure to wireless devices on different organs have been increased nowadays; however the effect on the lung is not clear. This study was conducted to figure out the histological changes in lung tissues after exposure to radiation emitted from router device and its relation to the duration of exposure.

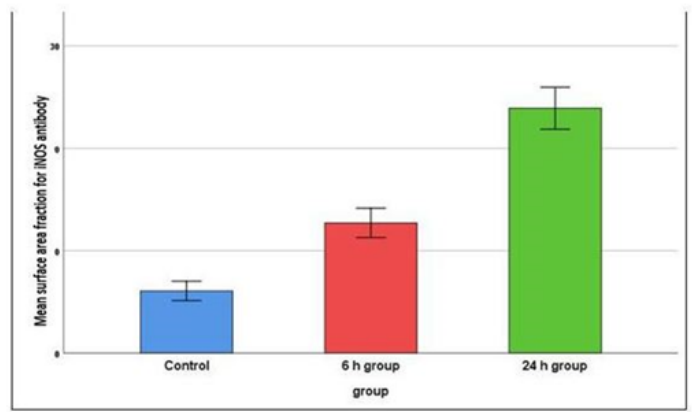

Histogram II: Comparison of mean surface area fraction of iNOS among the three groups

This work tried to simulate the same conditions that most people exposed; 6 hours group were exposed to Wi-Fi router for 6 hours per day from 9 am to $3 \mathrm{pm}$, the same duration that the employees are exposed to during their work. The $24 \mathrm{~h}$ group was exposed to Wi-Fi for 24 hours per day and this is the same duration that the most people are exposed in their homes. The router device $2.45 \mathrm{GHz}$ that was used is the commercial one that is used nowadays as done by Saili et al. ${ }^{[9]}$ in their study. The public type of commercial device was used instead of model of the generator of electromagnetic waves which is programmed at specific frequency and speed as the aim to simulate the actual condition that most people were exposed. 
By using hematoxylin and eosin the control group showed normal histological structure of the lung tissue. While the exposed groups to Wi-Fi router device showed many morphological changes in the form of marked dilatation and congestion of blood vessels of the exposed groups in compare with the control group. Which were very marked in the $24 \mathrm{~h}$ group if compared with the $6 \mathrm{~h}$ group. Some studies were in accordance with this study such as Mohamed ${ }^{[20]}$ and Esmekaya et al. ${ }^{[21]}$ who stated that the exposure to radiofrequency caused high level of nitric oxide in lung, liver, testes and heart, so dilatation of blood vessels might be due to increased nitric oxide production, which is a vasodilator.

In the exposed groups of this study, there were obvious thickening of inter-alveolar septa which increased in the septa of the $24 \mathrm{~h}$ group than the $6 \mathrm{~h}$ group. This could be explained by the presence of excess inflammatory cells, extravasated RBCs, congested capillaries. Collapsed of some alveoli with compensatory dilation of others was also noticed. The similar results were found by Hanafy et al. ${ }^{[22]}$ who reported thickening of inter-alveolar septa in his research on the lung of animals exposed to mobile phone radiations. In this study the inflammatory cells were found in large number mainly lymphocytes, macrophages and neutrophils. The inflammatory cells in the 24 hours group were mainly lymphocytes whereas in the 6 hours group mainly neutrophils. This observation was in accordance with Mohamed ${ }^{[20]}$ in his study on the lung exposed to EMR who observed many areas of lymphocytic infiltration around the bronchioles and blood vessels. The increase in neutrophil infiltration into the lung tissue was due to the activation of macrophages which synthesize interleukin-8 (a potent neutrophil chemotactic) and other inflammatory cells activation. This lead to increase in their number in the vascular space and interstitium areas ${ }^{[23]}$. In the current study there were many observations such as detachment of epithelial lining of some bronchioles, these results reinforced previous result observed by Mohamed ${ }^{[20]}$ who noticed the lumen of the bronchioles contained degenerated epithelial cells. Another observation was presence of homogenous acidophilic material present inside some alveoli and within inter-alveolar septa. $\mathrm{Hafez}^{[24]}$ who found similar results and explained this material is plasma exudates produced as result of damage of cell wall of the blood vessels. Alveolar macrophages were also detected by using charcoal injection. The results were analyzed statistically. There was a significant increase in the mean number of macrophages in 6 hours group in comparison to control group. Also there was a significant increase in 24 hours group in comparison to other groups. The increased number of macrophages may be due to their role in phagocytosis of particulate matter of inflammatory reaction and extravasated RBCs.

As regard of collagen fibers, Masson's trichrome stain used for assessment the effect of EMR exposure on stimulation of collagen fibers formation and deposition in lung tissue. There were minimal amount of collagen fibers in control group. While in the exposed groups there were increase of collagen deposition around the wall of the blood vessels and bronchioles even in the inter-alveolar septa. However the 24 hours group showed marked collagen fibers deposition in compare to 6 hours group. Fibroblast like cells was also observed. This was similar to Mohamed ${ }^{[20]}$ who showed increased collagen fibers in the areas around the pulmonary arteries, walls of the bronchioles and inside the thickened alveolar septa. The suggested mechanism for fibrosis may be due to stimulation activated macrophages and neutrophils to produce a variety of cytokines that amplify the inflammatory response and trigger fibroblast proliferation. Once fibroblasts become activated, they transform into myofibroblasts that secrete collagen ${ }^{[25]}$.

For further understanding the mechanism of damage immune-histochemical study was done using activated caspase 3 antibody. The results of this study showed negative immune expression in control group. This was in accordance with $\mathrm{Hafez}^{[24]}$ who also reported sections stained for caspase- 3 in the lung revealed no immune reaction of control group. In this study, positive immune expression cells was found in the 6 hours group and more marked in the 24 hours group and were seen in the in cells lining the alveoli, the bronchioles and cells scattered in the inter-alveolar septa. The statistical analysis of area fraction approved immne-histochemical results. There was a significant increase in the expression in 6 hours group in comparison to control group and in 24 hours group compared with other groups. Similar results were detected by Varghese et al. ${ }^{[26]}$ who reported an upregulation of caspase 3 genes was detected in the rats exposed to $2.45 \mathrm{GHz}$ radiation and the exposure to nonionizing radiation can disturb the apoptotic machinery in the brain. Additionally Shokri et al. ${ }^{[11]}$ revealed an increase in the activity of caspase- 3 in the testis of animal exposed to EMR for 7 hours. These results could be explained by Khaki et al. ${ }^{[27]}$ who reported that cellular damage caused by oxidative stress of as a result of exposure to EMR can induce apoptosis in various tissues of the body. On the other hand, it could be said that during chronic stress, there was abundant cellular debris and that numerous degenerate inflammatory cells fill and replace the alveolar spaces. These must be engulfed by macrophages, so all these apoptotic and phagocytic cells showed strong immuneexpression for caspase ${ }^{[17]}$. Oxidative stress of EMR on tissues was detected in this study from increased the level of expression of iNOS antibodies; there were little positive expression in the control lung and this agree with Cox et al. ${ }^{[28]}$ who showed similar results. While expression in the exposed group was increased. There was positive expression in many cells such as macrophages, bronchiolar epithelial cells and inflammatory cells in the inter-alveolar septa. Area fraction of three groups approved the previous results. There was a significant increase in the area fraction of iNOS expression in 6 hours group in comparison 
to control group and also increasein 24 hours group in comparison to other groups. This could be explained by Liu et al. ${ }^{[29]}$ who reported that iNOS expressed by activated macrophages and induced by a variety of proinflammatory cytokines. So, when lung exposed to oxidative stress NO react with the superoxide free radicals leading to lipid peroxidation in cell membranes ${ }^{[30]}$. The role of EMR in inducing oxidative stress has been also approved by Oksay et $a l^{[31]}$. From previous data, the mechanism by which EMR induced damage can be simplified by production of reactive oxygen species (ROS) $)^{[32]}$ and significant decrease in total antioxidant after EMF exposure ${ }^{[33]}$. These free radicals lead to damage of large cellular molecules such as lipids, proteins and nucleic acid and induce cell apoptosis $^{[32]}$.

\section{CONCLUSION}

From this study, the exposure to Wi-Fi router devices can cause many morphological changes in the lung tissue in the form of marked inflammatory reactions, congestion and dilation of blood vessels, increasing inter-alveolar septum thinking, extravasation of RBCs and fibrosis. These results due to the effect electromagnetic radiation in induction of apoptosis and oxidative stress. The hazardous effects of Wi- Fi router devices were time dependent.

\section{RECOMMENDATION}

Nowadays, the utilization of Wi-Fi routers devices becomes unavoidable in work and inside our homes. If we cannot stop use such devices, at least we should control the usage of these devices through minimizing the exposure time to save our health. Many precautions suggested such as turn off Wi-Fi router devices especially at sleep time. Use wire mode instead of wireless mode if available. Put the device in a room away from direct exposure.

\section{CONFLICT OF INTEREST}

There are no conflicts of interest

\section{REFERENCES}

1. D'Angelo C, Costantini E, Kamal M, Reale M. Experimental model for ELF-EMF exposure: Concern for human health. Saudi journal of biological sciences. 2015;22(1):75-84.

2. Taheri M, Mortazavi S, Moradi M, Mansouri S, Hatam G, Nouri F. Evaluation of the effect of radiofrequency radiation emitted from Wi-Fi router and mobile phone simulator on the antibacterial susceptibility of pathogenic bacteria Listeria monocytogenes and Escherichia coli. Dose-Response. 2017;15(1):1559325816688527.

3. Collins L, Ellis SR. Mobile devices: Tools and technologies: CRC Press; 2015.

4. Dasdag S, Akdag MZ, Erdal ME, Erdal N, Ay OI, Ay ME, et al. Effects of $2.4 \mathrm{GHz}$ radiofrequency radiation emitted from Wi-Fi equipment on microRNA expression in brain tissue. International journal of radiation biology. 2015;91(7):555-61.

5. Kivrak EG, Yurt KK, Kaplan AA, Alkan I, Altun G. Effects of electromagnetic fields exposure on the antioxidant defense system. Journal of microscopy and ultrastructure. 2017;5(4):167-76.

6. Çelik Ö, Kahya MC, Nazıroğlu M. Oxidative stress of brain and liver is increased by Wi-Fi $(2.45 \mathrm{GHz})$ exposure of rats during pregnancy and the development of newborns. Journal of chemical neuroanatomy. 2016;75:134-9.

7. Pooladi M, Montzeri A, Nazarian N, Taghizadeh B, Odoumizadeh M. Effect of WiFi waves $(2.45 \mathrm{GHz})$ on aminotransaminases (ALP, ALT and AST) in liver of rat. Archives of Advanced in Bioscience. 2018;9(2):13-20.

8. Deniz ÖG, Kıvrak EG, Kaplan AA, Altunkaynak BZ. Effects of folic acid on rat kidney exposed to $900 \mathrm{MHz}$ electromagnetic radiation. Journal of Microscopy and Ultrastructure. 2017;5(4):198-205.

9. Saili L, Hanini A, Smirani C, Azzouz I, Azzouz A, Sakly M, et al. Effects of acute exposure to WIFI signals $(2.45 \mathrm{GHz})$ on heart variability and blood pressure in Albinos rabbit. Environmental toxicology and pharmacology. 2015;40(2):600-5.

10. Khaki AA, ALIHEMMATI A, Nobahari R. A study of the effects of electromagnetic field on islets of Langerhans and insulin release in rats. 2015.

11. Shokri S, Soltani A, Kazemi M, Sardari D, Mofrad FB. Effects of Wi-Fi $(2.45 \mathrm{GHz})$ exposure on apoptosis, sperm parameters and testicular histomorphometry in rats: a time course study. Cell Journal (Yakhteh). 2015;17(2):322.

12. Reddy VBM. Biochemical Alterations as Markers of Mobile Phone Radiation in Mice. RESEARCH JOURNAL OF PHARMACEUTICAL BIOLOGICAL AND CHEMICAL SCIENCES. 2017;8(2):1808-15.

13. Iarc W. IARC Classifies Radiofrequency Electromagnetic Fields as Possibly Cancinogenic to Humans. International Agency for Research on Cancer, Lyon, Tech Rep. 2011.

14. Othman H, Ammari M, Rtibi K, Bensaid N, Sakly M, Abdelmelek H. Postnatal development and behavior effects of in-utero exposure of rats to radiofrequency waves emitted from conventional WiFi devices. Environmental toxicology and pharmacology. 2017;52:239-47.

15. Suvarna KS, Layton C, Bancroft JD. Bancroft's Theory and Practice of Histological Techniques E-Book: Elsevier Health Sciences; 2018.

16. Saber E. Switching in the sites of haemopoiesis in the spleen and bone marrow of mice during late prenatal 
and early postnatal life and the role of scavenger macrophages. Egypt J Anat. 2002;25:55-89.

17. Saber EA, Abd El Aleem MM, Aziz NM, Ibrahim RA. Physiological and structural changes of the lung tissue in male albino rat exposed to immobilization stress. Journal of cellular physiology. 2019;234(6):9168-83.

18. Seys LJ, Verhamme FM, Schinwald A, Hammad H, Cunoosamy DM, Bantsimba-Malanda $\mathrm{C}$, et al. Role of $\mathrm{B}$ cell-activating factor in chronic obstructive pulmonary disease. American journal of respiratory and critical care medicine. 2015;192(6):706-18.

19. Suhag A, Larik R, Mangi G, Khan M, Abbasi S, Madiha H. Impact of excessive mobile phone usage on human. J Comput Sci Syst Biol. 2016;9:173-7.

20. Mohamed AK. The possible rescue effect of vitamin E or Silymarin on lung tissue of male albino rats exposed to electro-magnetic field. The Egyptian Journal of Hospital Medicine. 2014;31(1587):1-20.

21. Esmekaya MA, Ozer C, Seyhan N. 900 MHz pulsemodulated radiofrequency radiation induces oxidative stress on heart, lung, testis and liver tissues. Gen Physiol Biophys. 2011;30(1):84-9.

22. Hanafy LK, Karam SH, Saleh A. The adverse effects of mobile phone radiation on some visceral organs. Research Journal of Medicine and Medical Sciences. 2010;5(1):95-9.

23. Rubin R, Strayer DS, Rubin E. Rubin's pathology: clinicopathologic foundations of medicine: Lippincott Williams and Wilkins; 2008.

24. Hafez MS. Effect of selenium supplementation on the structure of the lung of adult albino rats subjected to experimentally induced chronic renal failure. Egyptian Journal of Histology. 2012;35(3):573-86.

25. Wynn TA. Integrating mechanisms of pulmonary fibrosis. Journal of Experimental Medicine. 2011;208(7):1339-50.
26. Varghese R, Majumdar A, Kumar G, Shukla A. Rats exposed to $2.45 \mathrm{GHz}$ of non-ionizing radiation exhibit behavioral changes with increased brain expression of apoptotic caspase 3. Pathophysiology. 2018;25(1): 19-30

27. Khaki A, Fathiazad F, Nouri M, Khaki AA. Effect of Ocimum basilicum on apoptosis in testis of rats after exposure to electromagnetic field. African journal of Pharmacy and Pharmacology. 2011;5(12):1534-7.

28. Cox RA, Jacob S, Oliveras G, Murakami K, Enkhbaatar P, Traber L, et al. Pulmonary expression of nitric oxide synthase isoforms in sheep with smoke inhalation and burn injury. Experimental lung research. 2009;35(2):104-18.

29. Liu W-w, Han C-h, Zhang P-x, Zheng J, Liu K, Sun $\mathrm{X}-\mathrm{j}$. Nitric oxide and hyperoxic acute lung injury. Medical gas research. 2016;6(2):85

30. Han ZH, Jiang Y, Duan YY, Wang XY, Huang Y, Fang TZ. Protective effects of hydrogen sulfide inhalation on oxidative stress in rats with cotton smoke inhalation-induced lung injury. Experimental and therapeutic medicine. 2015;10(1):164-8.

31. Oksay T, Naziroğlu M, Doğan S, Güzel A, Gümral N, Koşar P. Protective effects of melatonin against oxidative injury in rat testis induced by wireless $(2.45$ GHz) devices. Andrologia. 2014;46(1):65-72.

32. Balci M, Devrim E, Durak I. Effects of mobile phones on oxidant/antioxidant balance in cornea and lens of rats. Current Eye Research. 2007;32(1):21-5.

33. Khaki AA, Khaki A. Amelioration of myocardial apoptosis by using Ocimum basilicum in rats after exposure to electromagnetic field (EMF): light and transmission microscopic study. 


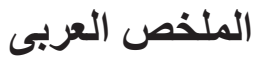

\section{تأثير التعرض لاشعاع جهاز توجيه الواي فاي علي رئة ذكور الجرذان

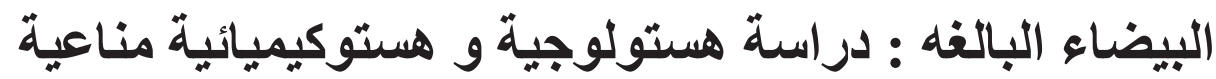

\author{
عزه حسين علي، هناء حسنين محمد، راندا احمد ابراهيم، نوره حسن خميس
}

قسم الهستولوجي وبيولوجيا الخليه ـ كليه الطب ـ جامعه المنيا ـ مصر

المقدمة: شهدت السنوات الأخيرة زيادة ملحوظة في استخدام أجززة الوابي فاي في الحياة اليومية. وقد ثبت ان استخدام هذه التكنولوجيا الجديدة قد يتسبب في حدوث العديد من المخاطر الصحية. الهدف من البحث: أجريت هذه الدراسة بهدف معرفة تأثير التعرض للإشعاعات المنبعثة من جهاز توجيه الواي فاي

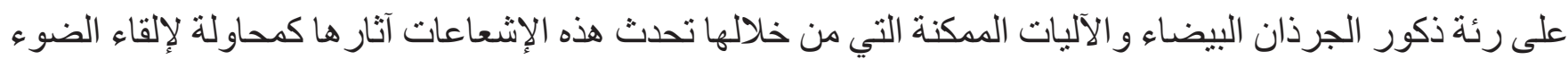
على مخاطر استخدام هذه التكنولوجيا في حياتتا اليومية. مواد وطرق البحث: أجريت هذه الدراسة على ·r من ذكور الجرذان البيضاء، تعرضت هذه الجرذان لإشعاع

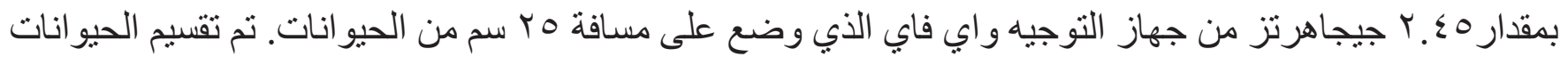

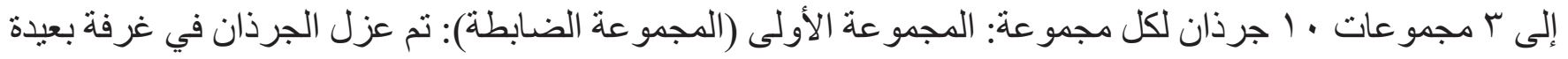
عن أي مصدر للاشعاع. المجموعة الثانية (7 ساعات): تعرضت الجرذان الجان لجهاز التوجيه لمدة 7 ساعات يوميًا لمدة

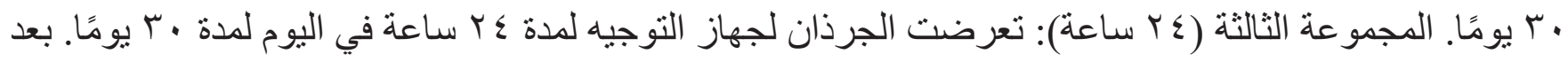

ذللك تم تجهيز الرئة للار اسة باستخدام الميكروسكوب الضوئى و عمل در اسات مناعية هستوكيميائية وقياسية.

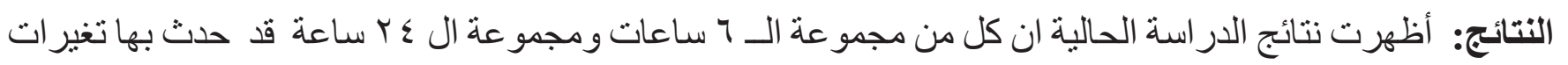

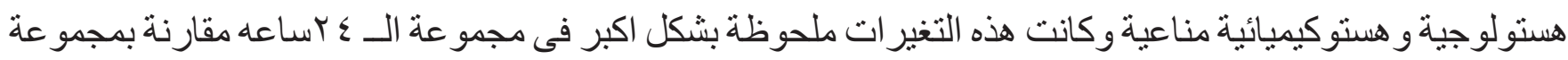
الـ 7 ساعات.

الاستتناج: من هذه الدر اسة يمكننا ان نخلص الى انه حيث لا يمكن تجنب استخدام أجززة توجيه الواي فاي في العمل و المدارس وداخل مناز لنا. لذلك إذا لم نتمكن من إيقاف استخدام هذه الأجهزة، فعلى الأقل يجب علينا التحكم في استخدام هذه الأجهزة من خلال تقليل وقت التعرض لها للحفاظ على صحتنا. 